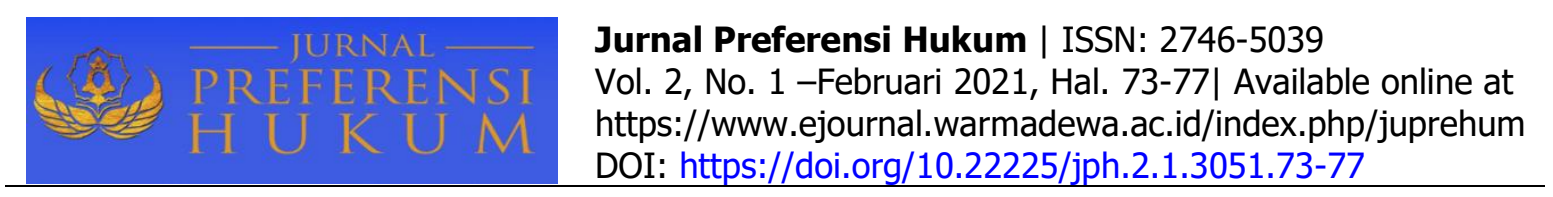

\title{
IMPLIKASI PENANAMAN MODAL DALAM NEGERI TERHADAP TINGKAT PENGANGGURAN DI KAWASAN PARIWISATA CANDIDASA KARANGASEM
}

\author{
Ni Made Budi Kartika, Desak Gde Dwi Arini, Luh Putu Suryani \\ Fakultas Hukum Universitas Warmadewa Denpasar, Bali, Indonesia
}

\begin{abstract}
Abstrak
Negara Indonesia merupakan Negara yang mempunyai banyak penduduk, serta mempunyai sumber daya alam yang melimpah, namun belum efektif dimanfaatkan untuk meningkatkan pertumbuhan ekonomi maupun menanggulangi pengangguran di Indonesia, kebijakan dasar dari penanaman modal yaitu Undang-Undang No. 25 Tahun 2007, Kabupaten Karangasem mempunyai daya tarik untuk penanaman modal dalam Negeri maupun asing untuk berinvestasi di daerah tersebut khususnya di Kawasan pariwisata Candidasa, karena memiliki letak geografis yang dekat dengan pantai, serta Candidasa ini sangat strategis, sehingga menarik investor untuk menanamankan modalnya diwilayah pariwisata Candidasa ini, serta mengembangkan usahanya untuk menggerakan roda perekonomian dalam jumlah yang cukup untuk membangun perekonomian dan mengurangi tingkat pengangguran yang ada di Kabupaten Karangasem. Penelitian ini bertujuan untuk menjelaskan bentuk penanaman modal dalam Negeri di Candidasa Karangasem dan untuk mengetahui implikasi penanaman modal dalam Negeri terhadap tingkat pengangguran di kawasan pariwisata Candidasa Karangasem. Penelitian ini menggunakan penelitian hukum empiris serta analisis data secara kualitatif dan kuantitatif, sumber data yang digunakan adalah data yang diperoleh dari penelitian lapangan (field research). Data sekunder, yaitu sumber data yang diperoleh dari penelitian kepustakaan, data-data dan bahan lain diperoleh dari literatur-literatur dan peraturan perundang-undangan yang berkaitan dengan permasalahan yang diteliti. Hasil penelitian menunjukkan bahwa penanaman modal dalam negeri berpengaruh positif kepada pengangguran yang ada di kawasan pariwisata Candidasa Karangasem. Selanjutnya, implikasi penanaman modal dalam negeri terhadap tingkat pengangguran memberi dampak positif bagi pengangguran yang ada dikawasan ini, karena dalam membangun usaha syaratnya dalam izin usaha tersebut harus mencantumkan surat keterangan yang $70 \%$ tenaga kerja harus diserap dengan mempekerjakan penduduk lokal.
\end{abstract}

Kata Kunci : Penanaman Modal; Pengangguran; Kawasan Pariwisata Candidasa.

\begin{abstract}
The State of Indonesia is a country that has a large population and abundant natural resources, but has not been effectively utilized to increase economic growth or tackle unemployment in Indonesia, the basic policy of investment is Law No. 25 of 2007, Karangasem Regency has an attraction for domestic and foreign investment to invest in the area, especially in the Candidasa tourism area, because it has a geographical location close to the coast, and Candidasa is very strategic, so that it attracts investors to invest in tourism areas. Candidasa, as well as developing its business to move the wheels of the economy in a sufficient amount to build the economy and reduce the unemployment rate in Karangasem Regency. This study aims to explain the form of domestic investment in Candidasa Karangasem and to determine the implications of domestic investment on the unemployment rate in the Candidasa Karangasem tourism area. This research uses empirical legal research as well as data analysis qualitatively and quantitatively, the data source used is data obtained from field research (field research). Secondary data, namely the source of data obtained from library research, data and other materials obtained from literatures and laws and regulations relating to the problems studied. The results show that domestic investment has a positive effect on unemployment in the Candidasa Karangasem tourism area. Furthermore, the implications of domestic investment on the unemployment rate have a positive impact on unemployment in this region, because in building a business the conditions in the business license must include a certificate that $70 \%$ of the workforce must be absorbed by employing local residents.
\end{abstract}

Keywords: Investment; Unemployment; Candidasa Tourism Area.

\section{PENDAHULUAN}

Negara Indonesia merupakan negara yang berkembang, Indonesia memiliki jumlah penduduk yang cukup banyak di kawasan Benua Asia, juga memiliki sumber daya alam yang cukup melimpah, maka dari itu Indonesia juga disebut kaya akan sumber daya alam dan sumber daya manusianya (Mirza et al., 2017). Kekayaan sumber daya alam memberikan keuntungan yang besar bagi perekonomian 
Indonesia, tetapi hal tersebut belum dapat perhatian lebih oleh pemerintah, yang seharusnya pemerintah dapat merangkul masyarakat untuk memajukan kesejahtraan negaranya (Rusliani, 2015). Hal tersebut disebabkan karena pemerintah Indonesia belum dapat mengefesiensikan sumber daya alam dan sumber daya manuisa yang melimpah, dari situlah muncul masalah yang dimiliki oleh pemerintah Indonesia untuk memajukan Negaranya. Salah satu masalah di Indonesia juga adalah banyaknya lulusan atau sumber daya manusia yang masih sampai sekarang pengangguran. Pengangguran merupakan salah satu masalah yang selalu ada dan sulit untuk dihindari dibeberapa negara berkembang maupun di negara maju (Febryani \& Kusreni, 2017). Namun pada umumnya tingkat pengangguran cenderung lebih banyak dihadapi oleh negara yang sedang berkembang seperti Indonesia. Pengangguran disini merupakan keadaan dimana seseorang tidak mempunyai pekerjaan, bekerjanya kurang dari waktu kerja, dan atau seseorang yang sedang mencari kerja. Pengangguran juga disebabkan karena jumlah pencari kerja lebih banyak dari pada lapangan pekerjaan yang tersedia.

Tingginya angka pengangguran menyebabkan dampak buruk yang dapat menimbulkan masalah sosial seperti terjadi tindakan kriminalitas dan kemakmuran masayarakat, semakin turunnya tingkat kemakmuran di Indonesia akan menimbulkan masalah seperti kemiskinan. Tidak ada negara yang tanpa memiliki pengangguran dan tingkat pengangguran itu menjadi suatu alat dasar untuk mengukur kinerja ekonomi di setiap Negara berkembang dan di Negara maju. Tingkat pengangguran juga sebagai indikator bagi para investor dalam Negeri dan asing untuk menganalisis sehat atau tidaknya perekonomian disuatu negara yang dijadikan lokasi investasikan oleh para investor, serta menggambarkan stabilnya perekonomian sehingga investor dalam negeri dan asing tertarik untuk berinvestasi.

Berdasarkan hasil observasi awal yang dilaksanakan pada tanggal 15 Agustus 2018 di Badan Pusat Statistik (BPS) Kabupaten Karangasem, pengangguran terbuka mengalami kenaikan dan penurunan yaitu pada tahun 2014 sebanyak 576 pengangguran, 2015 sebanyak 1.062 pengangguran, 2016 sebanyak 836 pengangguran, 2017 sebanyak 1.021 pengangguran. Efek dari sumber daya manusia yang masih kurang terampil dalam beberapa pekerjaan, karena perusahaan, hotel, restaurant dan yang lainnya membutuhkan sumber daya manusia yang memiliki skill yang kreatif dan cekatan, maka dari itu banyak pencari kerja yang belum dapat terserap dibeberapa lapangan pekerjaan.

Program pembangunan nasional ditegaskan dengan disebutkannya kebijakan dan penyelenggaraan penanam modal yang dilakukan oleh pemerintah dengan mewujudkan dalam instrumen kebijakan yang berupa peraturan perundang-undangan dan peraturan pemerintah (Ilmar, 2006). Kebijakan dasar penanaman modal berada di dalam bab III Pasal 4 ayat (1) Undang-Undang No. 25 Tahun 2007 tentang penanaman modal bahwa pemerintah menetapkan kebijakan dasar penanaman modal untuk mendorong terciptanya iklim usaha nasional yang kondusif bagi penanaman modal guna memperkuat daya saing perekonomian nasional. Berdasarkan Undang-Undang tersebut Pemda Karangasem memiliki kesempatan untuk menarik investor dalam rangka menanamkan modal baik dalam negeri maupun asing. Wilayah pariwisata Candidasa sangat layak untuk lebih dioptimalkan sebagai kawasan pariwisata di Karangasem, walaupun saat ini sudah terdapat beberapa lokasi wisata namun faktanya belum optimal dalam penataannya.

Jika dilihat dari segi akses wisata daerah Candidasa mudah untuk diakses dengan menggunakan transportasi darat karena melewati jalan trans nasional. Kondisi ini sebenarnya secara investasi disenangi oleh pengunjung wisata karena dekat dengan fasilitas umum lainnya, dari hal tersebut jika tepat dan cermat di optimalkan oleh memerintah yang berwenang akan memudahkan pertumbuhan ekonomi yang berdampak langsung pada pengurangan pengangguran di Kabupaten Karangasem. Ada beberapa peneliti terdahulu yang melakukan penelitian yang relevan dengan penelitian ini yaitu Mustika, (2006) mengkaji tentang kebijakan muamalah pemerintah indonesia terhadap sumber daya alam investasi swasta sektor pariwisata dan penyerapan tenaga kerja di provinsi bali (sebuah analisis tipologi daerah). Penelitian lain mengungkapkan bahwa mengoptimalkan potensi pariwisata dengan cara mendorong Pemerintah Kabupaten Cianjur menjalin kemitraan dengan pihak swasta (investor/penanam modal) untuk ikut berperan serta menanamkan investasinya dalam penyediaan infrastruktur pariwisata (Kamilah, 2017). Investasi asing berpengaruh positif dan signifikan secara langsung terhadap pertumbuhan ekonomi (Damayanti \& Kartika, 2016). Dari uraian bebrapa terahulu, maka penelitian ini dilakukan bertujuan untuk mengetahui tentang bentuk penanaman modal dalam negeri yang ada dikawasan pariwisata Candidasa Karangasem dan menjelaskan tentang implikasi dari 
penanaman modal dalam negeri terhadap tingkat pengangguran yang ada dikawasan pariwisata Candidasa Karangasem.

\section{METODE PENELITIAN}

Penelitian didesain menggunakan penelitian hukum empiris, dengan menelaah ketentuan normative yang diterapkan dalam praktek hukum nondoktrinal untuk menemukan jawaban-jawaban yang benar dengan pembuktian kebeneran fakta-fakta sosial sebagaimana terdapat dalam kehidupan sehari-hari (Sulistyowati \& Shidarta, 2009). Pendekatan yang digunakan yaitu pendekatan peraturan perundangundangan yang dikaji akan berkaitan dengan peraturan perundang-undangan yang berlaku dan berkaitan dengan penanaman modal, pendekatan konseptual terhadap pandangan-pandangan atau doktrin yang berkembang dalam ilmu hukum untuk menyelesaikan isu-isu hukum yang ada dalam penelitian ini, serta pendekatan sosiologi ilmu yang mempelajari tentang kehidupan bersama dan bermasyarakat (Bambang, 2002). Sumber data dalam penelitian ini adalah Data primer yaitu data yang diperoleh dari penelitian lapangan (field research). Data sekunder yaitu data yang diperoleh dari penelitian kepustakaan, data-data dan literatur-literatur lain yang berkaitan dengan permasalahan yang sedang diteliti. Data dikumpulkan melalui studi dokumentasi dengan cara mengumpulkan, membaca, mempelajari kutipan serta menelaah bahan-bahan pustaka berupa karya tulis dari para ahli yang disusun dalam litelatur dan peraturan perundangan.

\section{HASIL DAN PEMBAHASAN}

\section{Bentuk Penanaman Modal dalam Negeri di Candidasa Karangasem}

Penanaman Modal merupakan istilah yang digunakan dalam dunia bisnis di Indonesia namun investasi lebih terkenal dan dikenal oleh kalangan pembisnis karena istilah penanaman modal lebih banyak disebutkan dalam peraturan perundang-undangan. Seperti beberapa ahli maupun UU No.25 Tahun 2007 tentang penanaman modal. penanaman modal atau yang lebih dikenal investasi adalah segala bentuk macam-macam kegiatan bisnis yang dijalankan oleh pembisnis dalam Negeri maupun luar Negeri yang menanamkan modalnya di Indonesia dengan tujuan untuk memperoleh keuntungan. Penanaman modal dapat dibagi menjadi dua yaitu penanaman modal asing (PMA) dan penanaman modal dalam negeri (PMDN) (Yoantha, 2015). Dasar hukum penanaman modal atau Investasi di Indonesia sebelum dikeluarkannya UU No.25 Tahun 2007 tentang Penanaman Modal terdapat 2 (dua) Undang-undang di bidang penanaman modal yaitu UU No. 1 Tahun 1967 tentang Penanaman Modal Asing serta UU No. 6 Tahun 1968 tentang penanaman modal dalam Negeri. Selanjutnya kedua undang-undang tersebut di amandemen tahun 1971 dan selanjutnya tahun 2007 lahirlah UU No.25 Tahun 2007 tentang penanaman modal yang mengatur keseluruhan PMDN dan PMA.

Bentuk penanaman modal dalam negeri yang ada di Candidasa Karangasem adalah Penanaman Modal Langsung direct investment. Sebelum menjelaskan hal tersebut terlebih dahulu mengenal bentuk dan jenis penanman modal di Indonesia secara singkat. Penanaman modal dalam negeri bersifat kegiatan usaha terbuka, namun ada pengecualian sesuai dengan Perpres No.36 Tahun 2010 tentang perubahan daftar bidang usaha yang tertutup dan bidang usaha yang terbuka dengan persyaratan di bidang penanaman modal dan bab iv pasal 5 UU No. 25 Tanhun 2007 tentang penanaman modal yang menjelaskan kedudukan penanaman modal dan bentuk badan usaha.

Bentuk-bentuk kerja sama penanaman modal secara keseluruhan terdiri dari beberapa macam yaitu:

1) Joint venture kerjasama yang dilakukan oleh pemodal asing berkerja sama dengan Pemodal dalam Negeri namun semata-mata hanya dalam perjanjian kerjasama yang sah. Selanjtnya Joint venture dibagi menjadi tiga yaitu build Operation and transfer yaitu betuk kerjasama yang objeknya bangunan, kedua technical assistance yaitu bentuk kerjasama dalam bidang skill dan cara kerja atau metode kerja, ketiga franchise and branduse Agreement yaitu kerjasama mengenai produksi suatu produk ternama.

2) Kontrak karya yaitu kerjasama dengan membentuk badan hukum di Indonesia dengan modal asiang atau modal dalam negeri.

3) Portofolio Invesment yaitu bentuk kerjasama melalui pembelian saham suatu perusahaan di dalam negeri.

4) Penanaman modal dengan kredit investasi yaitu praktik yang pada umumnya penanam modal dalam negeri membiayai proyeknya yang ada di Indonesia. 
5) Production sharing yaitu bentuk kerja sama asing yang memebrikan modal kepada pemodal dalam negeri yang penggantinya adalah hasil tersebut harus di ekspor ke pemodal asing di luar Negeri.

Bentuk penanaman modal dalam Negeri di kawasan pariwisata Candidasa Kabupaten Karangasem menggunakan bentuk penanaman modal secara langsung (direct investment), yang mana investor atau penanam modal secara langsung dapat melihat bagaimana pengelolaan modalnya tersebut, serta pihak penanam modal bisa langsung ikut dalam kegiatan untuk mengelola dan bertanggung jawab terhadap kegiatan bisnis tersebut. Dalam kawasan pariwisata Candidasa ini tidak semua juga berbadan hukum ada pula perusahaan yang tidak berbadan hukum seperti hotel, villa, dan atau restoran makanan.

\section{Mengetahui Implikasi Penanaman Modal dalam Negeri Terhadap Tingkat Pengangguran di Kawasan Pariwisata Candidasa Karangasem}

Implementasi penanaman modal di Candidasa yang mana pemerintah Kabupaten Karangasem (Amlapura) sudah berusaha dengan meningkatkan prekonomian pada bidang pariwisata, meningkatkan taraf hidup dan mengurangi pengangguran masyarakat Karangasem. Dari hal tersebut memberikan angin segar kepada investor yang ingin menanamkan modalnya di kawasan pariwisata Candidasa. Berdasarkan hasil laporan kepala penanaman modal di dinas penanaman modal satu pintu yaitu penerapan investasi di Candidasa memberikan dampak positif bagi kegiatan investasi yang tujuannya mensejahterakan masyarakat serta mendongkrak pembangunan Nasional. Maka berangkat dari hal tersebut pemerintah gencar dalam memberikan peraturan-peraturan yang menguntungkan namun terbatas agar tidak menyalahi peraturan perundang-undangan Nasional.

Untuk diketahui bahwa investasi penanaman modal di Candidasa berlaku berbagai macam waktu dan bentuk artinya bejalannya investasi disepakati pemodal yang sesuai dengan peraturan perundangundangan sehingga tidak menyalahi aturan karena kerap dijadikan modus mencari untung sebesarbesarnya tanpa mempedulikan dampak buruknya. Investasi yang dilakukan di Candidasa sebetulnya telah mengimplementasikan visi dan misi pemerintahan saat ini di Kabupaten Karangasem dengan menyerap tenaga kerja local di kawasan tersebut namun tak semudah itu karena pengusaha harus mencari izin usaha sesuai aturan daerah dan nasional.

Implikasi penanaman modal dalam Negeri terhadap tingkat pengangguran di kawasan pariwisata Candidasa Karangasem. Hal ini menitik beratkan kepada dampak positif dalam penanam modal dalam Negeri secara mumum sebagai salah satu penambah pendapatan nasional misalkan dalam pajak-pajak usaha bisnis dalam pariwisata. Ini sangat berpengaruh dalam perkembangan yang baik di bidang ekonomi investasi. Tidak hanya itu pula implikasi penanaman modal dalam Negari membahas mengenai pengeluaran atau belanja yang dilakukan pemodal yang menjadikan keuntungan bagi bangsa akan bertambah sebagai pendongkrak pertumbuhan ekonomi yang baik di masa akan datang. Investasi penanaman modal dalam Negeri mempengaruhi dalam hal positif juga dalam mengurangi tingkat pengangguran yang ada di Indonesia dengan membuka lapangan pekerjaan yang lebih banyak dan kesempatan kerja yang lebih terbuka namun perlu diimbangi dengan tenaga kerja yang terampil itu pula menjadi tugas pemerintah untuk memberikan pelatihan-pelatihan kerja yang terampil bagi calon-calon pencari kerja.

Penanaman modal atau investasi yang dilakukan di Indonesia berdampak seperti pembukaan lapangan kerja baru, alih teknologi baru, pengingkatan pendapatan Negara dari sektor pajak, memudahkan masyarakat memenuhi kebutuhan hidup dan mendorong kemajuan produsen dalam Negeri. Tidak hanya itu terdapat pula dampak positifnya yaitu terbengkalainya sektor pertanian Nasional dan local, kerusakan lingkungan secara langsung maupun tidak langsung, berkurangnya lahan produktif karena mengingat dalam membuka usaha bisnis tak banyak lahan produktif dialih fungsikan, eksplorasi sumber daya alam secara berlebihan dan hal terburuknya banyak hasil usaha dibawa ke Negara asalnya.

Implikasi investasi di kawasan pariwisata Candidasa terhadap angka pengangguran Dalam dokumen UKLUPL mencantumkan surat keterangan bahwa $70 \%$ tenaga kerja diserap baik untuk kegiatan bisnis penduduk lokal. Hal tersebut telah diteliti sebagi hasil pencapaian yang baik untuk pengurangan pengangguran di Kabupaten Karangasem. Peran pemerintah daerah Karangasem terkait dengan penanggulangan pengangguran yang masih ada di daerah ini yaitu sesuai hasil penelusuran pencarian data yaitu ditegaskan oleh Kepala Dinas Ketenaga kerjaan Kabupaten Karangasem bahwa sesuai dengan visi dan misi pemerintahan tahun ini, yang dalam rumusannya dalam rencana kerja 
Dinas Ketenaga kerjaan yaitu meningkatkan wira usaha muda, mengatasi pengangguran secara bertahap. Data pencari kerja secara terperinci di Kabupaten Karangaem Tahun 2015-2017 yaitu pada tahun 2015 pencari kerja sebanyak 1.062 dan penenpatan kerja sebagnyak 988, tahun 2016 pencari kerja sebanyak 836 dan penempatan kerja sebanyak 578 dan terakhir tahun 2017 terjadi peningkatan pencari kerja sebanyak 1.021 dan penempatanya pun meningkat sebesar 1.062 secara ilmu statistic di perdiksi terjadi keseimbangan. Menurut UPTD atau BLK terdapat 12 (dua belas) pengentasan kemiskinan dengan melakukan pelitah kerja dibidang yang sangat umum dibutuhkan yaitu administrasi perkantoran, mekanik junior sepeda motor, teknisi pendingin AC split, teknisi lemari pendingin, menjahit, instalasi penerangan, desain grafis, prosessing hasil pertanian dan perikanan, juru las, tata rias, SPA terapi dan perhotelan. Untuk menjalankan program tersebut pemerintah Kabupaten Karangasem telah menganggarkan biaya tersebut. Jadi cukup jelas implikasi yang didapat dan peran, fungsi serta tanggung jawab yang harus dilakukan oleh Pemerintah Kabupaten Karangasem untuk mensejahterakan masyarakatnya salah satunya mengurangi angka pengangguran di wilayahnya.

\section{SIMPULAN DAN SARAN}

\section{Simpulan}

Berdasarkan hasil analisis data, dapat disimpulkan bahwa bentuk penanaman modal atau investasi secara umum yang mana berbadan hukum maupun yang tidak berbadan hukum. Seperti Joint Venture, Portofolio Investment, Penanaman Modal Secara Langsung (Direct investment), Penanaman Modal Secara Tidak Langsung (Indirect investment). Bentuk penanaman modal dalam Negeri di Kawasan pariwisata Karangasem menggunakan bentuk penanaman modal secara langsung, dimana penanam modal dapat langsung terlibat dalam kegiatan pengelolaan usaha serta dapat bertanggungjawab kepada perusahaan apabila terjadi kerugiaan dalam perusahaan tersebut, selanjutnya implikasi penanaman modal dalam Negeri terhadap tingkat pengangguran memberi dampak positif bagi pengangguran yang ada dikawasan ini, karena dalam membangun usaha syaratnya dalam izin usaha tersebut harus mencantumkan surat keterangan yang $70 \%$ tenaga kerja harus diserap dengan mempekerjakan penduduk lokal.

\section{Saran}

Adapun yang menjadi saran penelti yaitu investor atau penanam modal dapat lebih jelas mengetahui apa saja bentuk-bentuk penanaman modal yang ada di Indonesia, dapat membagi kegiatan usaha yang berbadan hukum atau yang tidak berbadan hukum. Kepaada Pemerintah daerah Karangasem bagian UPTD atau BLK supaya memperluas wilayah sosialisasi tentang pelatihan-pelatihan kerja untuk mengurangi para pengangguran yang ada diwilayah-wilayah terpencil di Karangasem.

\section{DAFTAR PUSTAKA}

Bambang, W. (2002). Penelitian Hukum dalam Praktek. Sinar Grafika.

Damayanti, N. L. E., \& Kartika, I. N. (2016). Pengaruh Kunjungan Wisatawan Asing dan Investasi Terhadap Penyerapan Tenaga Kerja Serta Pertumbuhan Ekonomi. E-Jurnal EP Unud, 5(7), 882-900.

Febryani, T., \& Kusreni, S. (2017). Determinan Pertumbuhan Ekonomi di 4 Negara ASEAN. Jurnal Ilmu Ekonomi Terapan, 2(1), 10-20.

Ilmar, A. (2006). Hukum Penanaman Modal Indonesia. Kencana.

Kamilah, A. (2017). Investasi Pembangunan Pariwisata Melalui Model Build Operate And Transfer/Bot dalam Menghadapi Keterbatasan APBD Kabupaten Cianjur. Journal of Empowerment, 1(2), 71-86.

Mirza, A. C., Anggraini, R. A. R., \& Soetijono, I. R. (2017). Implementasi Pengelolaan Sumber Daya Laut Nasional Terhadap Kebijakan Pemerintah Provinsi Kepulauan Riau. E-Journal Lentera Hukum, 4(2), 5670.

Mustika, M. D. S. (2006). Kebijakan Muamalah Pemerintah Indonesia terhadap Sumber Daya Alam Investasi Swasta Sektor Pariwisata dan Penyerapan Tenaga Kerja di Provinsi Bali (Sebuah Analisis Tipologi Daerah). Jurnal Ekonomi Dan Sosial, 2(1), 15-19.

Rusliani, H. (2015). Kebijakan Muamalah Pemerintah Indonesia terhadap Sumber Daya Alam dan Sumber Daya Manus ia Sebagai Modal Pembangunan Ekonomi Indonesia. Jurnal Kontekstualita, 30(2), 206-219.

Sulistyowati, \& Shidarta. (2009). Metode Penelitian Hukum. ayasan Pustaka Obor Indonesia.

Yoantha, U. (2015). Akibat Hukum Pembelian Saham Perusahaan Bukan Penanaman Modal Asing oleh Warga Negara Asing atau Badan Hukum Asing. Jurnal Law, 3(1), 156-166. 